\title{
Antiviral effects of a synthetic Aluminium-Magnesium Silicate, on Avian Influenza Virus
}

\author{
Maduike C. O. Ezeibe ${ }^{1 *}$, Antony N. Egbuji ${ }^{2}$, Obianuju N. Okoroafor ${ }^{1}$, James I. Eze $^{1}$, \\ Omadi ljabo ${ }^{1}$, Augustine A. Ngene ${ }^{1}$, Ikechukwu C. Eze ${ }^{3}$, Joseph A. C. Ugonabo ${ }^{3}$, \\ Mary E. Sanda ${ }^{1}$, ljeoma J. Mbuko ${ }^{1}$ \\ ${ }^{1}$ Department of Veterinary Medicine, University of Nigeria, Nsukka, Nigeria; \\ ${ }^{*}$ Corresponding Author: Ezeibe,MaduikeC.O.maduikeezeibe@yahoo.com \\ ${ }^{2}$ Viral Research Laboratory, National Veterinary Research Institute, Vom, Nigeria \\ ${ }^{3}$ Department of Microbiology, University of Nigeria, Nsukka, Nigeria
}

Received 6 January 2012; revised 24 February 2012; accepted 13 April 2012

\begin{abstract}
Effects a synthetic Aluminium-Magnesium Silicate [AMS] has on Avian Influenza Virus (AIV) were tested. Equal amounts of AIV samples and of the AMS were mixed, kept one hour at room temperature before centrifuging. The supernatants were remeasured and tested for, viral titre, Mean Death Time (MDT) and Mortality Rate of chicken Embryos (EMR). Volumes of the viral samples reduced at rate of $23.4 \% \pm 5.48 \%$. Viral titres reduced significantly $(P<0.01)$ from $H A$, $73 \pm 32.72$ to $1.4 \pm 0.43$. Also, EMR of infected chicken embryos reduced from $100 \%$ to $65 \%$, while MDT of those that died,increased significantly $(P<0.01)$ from $76 \pm 4.38$ to $136 \pm 18.93$ hours. When incubation with AMS was repeated on portions of an AIV sample, MDT increased from 64 to 104 hours with the portion incubated once. AIV portions on which incubation with AMS was repeated could not kill chicken embryos.
\end{abstract}

Keywords: Antiviral; Synthetic Aluminium-Magnesium Silicate; Avian Influenza Virus

\section{INTRODUCTION}

Avian Influenza Viruses are enveloped, single stranded, RNA viruses.Two different protein projections cover their envelopes. These are the Haemagglutinin $(\mathrm{H})$ and the Nueraminidase (NA) antigens. Different combinations of the $\mathrm{H}$ and NA antigens on envelopes of Influenza viruses is an important property of the genus because, it allows for resortment when different Influenza viruses replicate together in same cells.

Influenza viruses are classified into types, A, B and C, based on antigenic differences of their nucleocapsid and of their matrix proteins [1]. Avian Influenza Viruses are Influenza A viruses [2]. The Influenza A viruses are subdivided, serologically, into sixteen $\mathrm{H}$ and nine NA subtypes. All these subtypes infect avian species. However, they coexist with water fowls, sea birds and other wild birds which are their natural hosts, in perfect harmoney [2]. Disease outbreaks occur in domestic birds when they come in contact with these wild birds or with infected pigs [2]. The wild birds which are carriers of Influenza viruses shed them in their secretions and excretions. So, domestic birds can also get infected if they contact secretions or excretions of infected wild birds or with fomites [3].

Avian Influenza Viruses cause two main forms of disease, distinguished by low or high virulence, in domestic poultry. The low pathogenic form causes only ruffled feathers and drop in egg production while the Highly $\mathrm{Pa}$ thogenic Avian Influenza Viruses (HPAIV) spread rapidly between flocks, affect many organs of infected birds and lead to high mortality within 48 hours [3].

Genetic characterization of Avian Influenza Viruses isolated from outbreaks in Nigeria, in 2007, revealed a new reasortant virus, H5N1 [4]. Resortment occurs when an Influenza virus infects a humanbeing or a pig that is already infected with another Influenza virus. Such resortment of antigens (viral shift), can produce Influenza virus strains different from available vaccine strains. Viral shift led to human pandemics of 1918 and of 19571958. So, isolation of a new Influenza virus subtype in Nigeria is of great concern to the country, both for her poultry industry and for public health.

AMS is safe when ingested by man or animals. For this reason, it is used in many pharmaceutical formulations [5]. It is used in tableting drugs because, one end of it's molecules has a positive electrical charge and the other is negatively charged [6]. Viruses have electrical charges too. Some viruses have net positive electrical 
charges while others have net negative charges [7]. These electrical charges could make Influenza virus particles adsorb onto molecules of AMS. If this happens, first stage of viral infection, which is adsorption to hosts' cells may be inhibited.

Natural AMS has impurities [6]. These could cause adverse reactions on treated animals if ingested at the high doses that may be required to treat viral diseases. So, two medicinal minerals which occur in Nigeria, Aluminium Silicate $\left\{\mathrm{Al}_{4}\left(\mathrm{SiO}_{4}\right)_{3}\right\}$ and Magnesium Silicate $\left\{\mathrm{Mg}_{2} \mathrm{SiO}_{4}\right\}$ were reacted to get a synthetic AMS :

$\mathrm{Al}_{4}\left(\mathrm{SiO}_{4}\right)_{3}+3 \mathrm{Mg}_{2} \mathrm{SiO}_{4} \rightarrow 2 \mathrm{Al}_{2} \mathrm{Mg}_{3}\left(\mathrm{SiO}_{4}\right)_{3}[8]$.

\section{MATERIALS AND METHODS}

Samples of the H5N1 AIV, isolated from Nigeria were incubated with the AMS. To a measured volume of each viral sample, equivalent amount of the synthetic AMS, on volume to weight basis, was added. They were thoroughly mixed, kept at room temperature for one hour and centrifuged at 3000 revolutions per minute, for ten minutes. Their supernatants were measured for volume and tested for viral titre by the haemagglutination (HA) test [9]. Also, $0.1 \mathrm{ml}$ of each supernatant was inoculated into yolk sacs of two embryonated chicken eggs to test its ability to kill infected chicken embryos. The eggs were candled 4 hours post inoculation (PI) to confirm viability of the embyos after the viral inoculation. Candling for mortality of embryos due to the viral infection was done every 12 hours till 208 hours, PI, when the experiment was terminated to avoid the chicks hatchingout to contaminate the environment. MDT was calculated for each sample, using, time of first embryonic death $\left(D_{1}\right)$, time of second embryonic death $\left(\mathrm{D}_{2}\right)$ and the interval between egg inoculation and candling to confirm viability of the inoculated embryos (C), by the formula:

$$
\mathrm{MDT}=\frac{\mathrm{D}_{1}+\mathrm{D}_{2}}{2}+\mathrm{C}(4 \text { hour })
$$

As controls, intact portions of each of the AIV samples were used for HA test on same plates with supernatants of their portions incubated with the synthetic AMS. Also, portions of each of the intact viruses were used for egg inoculation along with supernatants of their portions incubated with the AMS. Means of the viral titres and of the MDT of the two groups were compared to test the null hypothesis, that AMS has no effect on titre and on pathogenicity of AIV, by the Student T-test $(n=10)$.

Portions of a sample of the H5N1 AIV which gave high HA titre were used to test effect of repeating incubation of AIV with the AMS, on titre of the virus and on MDT and EMR of chicken embryos inoculated with it. One portion was incubated with the AMS once. To a second portion, after the centrifugation, equal amounts of the AMS and of the supernatant were mixed and the in- cubation process was repeated once. In the third portion, incubation with the AMS was repeated twice. The three portions were then tested, for viral titre, MDT and EMR of chicken embryos infected with AIV.

\section{RESULTS}

Volumes of the viral samples reduced at rate of $23.4 \%$ $\pm 5.48 \%$ following incubation with the AMS. Also, incubation with the AMS significantly $(\mathrm{P}<0.01)$ reduced titre of the H5N1 AIV from HA, $73 \pm 32.72$ to $1.4 \pm 0.43$ and the EMR $(\mathrm{P}<0.01)$ from $100 \%$ to $65 \%$. Incubating AIV with the AMS increased MDT of chicken embryos inoculated with the virus significantly $(\mathrm{P}<0.01)$ from 76 \pm 4.38 to $136 \pm 18.93$ hours.

Repeating incubation of AIV with the AMS reduced titres of the viral portions from HA, 128 to, 2 in both the portion incubated with AMS once and in the two portions incubated twice and thrice respectively. EMR was $100 \%$ in the control and in eggs inoculated with AIV portion incubated with the AMS once, but their MDT increased from 64 hours in the control to 104 hours. In the groups of eggs inoculated with portions of the AIV incubated with the AMS twice and thrice respectively, there was no embryonic death, up to 208 hours PI.

Effects the AMS had on volume of $A I V$ samples, on the viral titres and on MDT and EMR of chicken embryos inoculated with the virus, are as on Tables 1-4.

\section{DISCUSSION}

Brooks [10] defined antiviral agents as substances which kill viruses or substances which inhibit replication or pathogenicity of viruses. Stern et al. [11], reported that pathogenicity of Myxoviruses is an activity of their haemagglutinin antigen. Since the synthetic AluminiumMagnesium Silicate inhibited agglutination of red blood cells, which is also an activity of the haemagglutinin antigen, of the H5N1, Avian Influenza Virus, reduced

Table 1. Volume of H5N1 Avian Influenza viral samples following incubation with the synthetic Aluminium-Magnesium Silicate.

\begin{tabular}{cccc}
\hline Virus samples & $\begin{array}{c}\text { Volume before } \\
\text { incubation }\end{array}$ & $\begin{array}{c}\text { Volume after } \\
\text { incubation }\end{array}$ & $\begin{array}{c}\text { Rate of } \\
\text { Reduction (\%) }\end{array}$ \\
\hline 1 & With AMS (ml) & with AMS (ml) & \\
2 & 13 & 10 & 21.1 \\
3 & 9 & 6.5 & 21.8 \\
4 & 6 & 3.5 & 30 \\
Mean & 3 & 2.5 & 16.7 \\
\hline
\end{tabular}

Incubating Avian Influenza Virus with the Aluminium-Magnesium Silicate significantly $(\mathrm{P}<0.01)$, reduced volume of the viral samples. 
Table 2. Titre of H5N1 Avian Influenza Virus incubated with the synthetic Aluminium-Magnesium Silicate.

\begin{tabular}{ccc}
\hline Virus Samples & \multicolumn{2}{c}{ HA Titre } \\
\hline 1 & Control & Incubated with AMS \\
2 & 256 & 4 \\
3 & 256 & 0 \\
4 & 128 & 0 \\
5 & 32 & 2 \\
6 & 32 & 2 \\
7 & 8 & 0 \\
8 & 8 & 2 \\
9 & 4 & 2 \\
10 & 4 & 2 \\
Mean & 2 & 0 \\
\hline
\end{tabular}

Incubating Avian Influenza Virus with Aluminium-Magnesium Silicate significantly $(\mathrm{P}<0.01)$, reduced the viral titres.

Table 3. Mean death time and embryo mortality rates of chicken eggs innoculated with H5N1 Avian Influenza Virus incubated with the synthetic Aluminium-Magnesium Silicate.

\begin{tabular}{ccccc}
\hline $\begin{array}{c}\text { Virus } \\
\text { samples }\end{array}$ & \multicolumn{2}{c}{$\begin{array}{c}\text { Mean Death } \\
\text { Time(Hours) }\end{array}$} & \multicolumn{2}{c}{$\begin{array}{c}\text { Embryo Mortality } \\
\text { Rate (\%) }\end{array}$} \\
\hline & $\begin{array}{c}\text { Incubated } \\
\text { with AMS }\end{array}$ & Control & $\begin{array}{c}\text { Incubated } \\
\text { with AMS }\end{array}$ & Control \\
\hline 1 & 112 & 88 & 100 & 100 \\
2 & 52 & 88 & 100 & 100 \\
3 & 76 & 40 & 100 & 100 \\
4 & 64 & 88 & 100 & 100 \\
5 & 148 & 76 & 50 & 100 \\
6 & 148 & 76 & 100 & 100 \\
7 & 136 & 76 & 100 & 100 \\
8 & 208 & 76 & 0 & 100 \\
9 & 208 & 76 & 0 & 100 \\
10 & 208 & 76 & 0 & 100 \\
Mean & $136.00 \pm 18.93$ & $76 \pm 4.38$ & $65 \pm 15.00$ & $100 \pm 0.00$ \\
\hline
\end{tabular}

Incubating Avian Influenza Virus with Aluminium-Magnesium Silicate significantly $(\mathrm{P}<0.01)$ increased Mean Death Time and significantly $(\mathrm{P}<0.01)$ reduced Embryo Mortality Rate of chicken eggs innoculated with the virus.

Table 4. HA titre of Avian Influenza Virus and MDT of infected chick embryos following repeated incubation of the virus with the synthetic Aluminium-Magnesium Silicate.

\begin{tabular}{ccc}
\hline Number of Repeat Incubations & HA Titre & MDT (Hours) \\
\hline 0 & 128 & 64 \\
1 & 2 & 104 \\
2 & 2 & $>208$ \\
3 & 2 & $>208$ \\
\hline
\end{tabular}

Rate at which the virus killed chicken embryos and delayed death in embryos that were killed, it suggests that the AMS had antiviral effect against the virus. Reduction in volume of the viral samples suggests that the synthetic AMS adsorbed onto water molecules in the samples. This action of the synthetic AMS agrees with reported effect of natural AMS on water [5]. Reduction in volume of viral samples should lead to increase in their viral titres if the AMS had no effect on the virus. However, the viral titres reduced in spite of the reduction in volume. This suggests that the electrostatic attraction between the AMS molecules and the viral particles was stronger than that between them and water molecules.Reduction in titre of the HPAI virus and inhibition of the viral activeties by AMS as seen in these experiments agree with earlier results of effect of the synthetic AMS on Peste des Petits Ruminants Virus [12], on Infectious Bursal Disease Virus [13], on Egg Drop Syndrome 76 virus [14], on Canine Parvovirus [15] and on Newcastle Disease Virus [16].

AMS is safe when ingested by man and by animals $[5,17]$. It is used to bind drugs to make tablets used in treating both humans and animals [6]. Foster and Smith [18] reported that AMS has been in use for treatment of ulcer for many years. Also, the synthetic AMS tested in this study, was got by reaction of Aluminium Silicate and Magnesium Silicate [8] which are medicines being used to treat both animals and humanbeings. So, the synthetic AMS is safe for treating viral diseases of man and of animals. It can be used for systemic treatment of infectious diseases, because, once there is inflammation of mucous membranes of the stomach or of the intestines unabsorbable subatances can pass into the blood which then carries them to different organs [19]. Also, simple sugars are reported to carry electrically charged molecules across intact mucous membranes, by active transport [20]. Dextrose monohydrate incorporated in the synthetic AMS [8] carries the AMS molecules across even intact mucousmembranes.

Ability of the AMS to inhibit replication and pathogenicity of the HPAI virus, as suggested by the significant increase in MDT and decrease in EMR recorded in these experiments, shows that it could be a good candidate for development of a drug for control of Bird Flu in poultry and for management of human cases of Avian Influenza.

\section{REFERENCES}

[1] Jordan, F.W.T. (1990) Poultry diseases. 3rd Edition, Bailliere Tindal, London.

[2] Webster, R.G., Peiris, M., Chen, H. and Guan, Y. (2006) $\mathrm{H}_{5} \mathrm{~N}_{1}$ outbreaks and enzootic influenza. Emerging Infectious Diseases, 12, 3-8. doi:10.3201/eid1201.051024 
[3] WHO (2005) Avian influenza Virus A (H5N1) infection in humans: Urgent need to eliminate the animal reservoirs. http/www.who.int/csr/don/2004.03.02/en/index.html

[4] Monne, I., et al. (2008) Resortant Avian Influenza Virus (H5N1) in poultry in Nigeria in 2007. Emerging Infectious Diseases, 14, 637-640. doi:10.3201/eid1404.071178

[5] Verndabilt, R.T. (1992) Inc. Technical Literature: Veegum ${ }^{\circledR}$ the versatile incredient for pharmaceutical formulations. $1-5$.

[6] Venkatakrishnan, R. (1995) Geology-An introduction to physical geology. Worth Publishers, New York.

[7] Cann, A.J. (1993) Principles of molecular virology. Academic Press, Cambridge.

[8] Ezeibe, M.C.O. (2006) Admacine ${ }^{\circledR}$. Federal Republic of Nigeria Patents No. 16448

[9] Johnson, R.H. (1971) Serological procedures for the study of Feline panleukopaenia. Journal of the American Veterinary Medical Association, 158, 876-884.

[10] Brooks, G.F. (1998) Medical microbiology. 21st Edition, Mc Graw Hill education Inc., SanFranscisco.

[11] Stern, I.B., Greenberg, M., Gersoni, J.M. and Rozenblatt, S. (1995) The haemaglutinin envelope protein of Canine distemper virus $(C D V)$ confers cell tropism as illustrated by $\mathrm{CDV}$-Measles virus complementation analysis. Journal of Virology, 69, 1661-1668.

[12] Ezeibe, M.C.O., et al. (2009) Antiviral effects of Aluminium-
Magnesium Silicate on Peste des Petits Ruminants Virus. Animal Science Papers and Reports, 3, 141-147.

[13] Ezeibe, M.C.O., et al. (2009) In vitro and in vivo effects of Aluminium-Magnesium Silicate on Infectious Bursal Disease Virus of chickens. Animal Science Papers and Reports, 3, 132-137.

[14] Ezeibe, M.C.O., et al. (2010) Haemagglutination and Haemagglutination-Inhibition titres of Egg Drop Syndrome 76 Virus treated with Aluminium-Magnesium Silicate. Animal Science Papers and Reports, 4, 87-90.

[15] Ezeibe, M.C.O., et al. (2010) Aluminium-Magnesium Silicate inhibits Canine Parvovirus and cures infected dogs. Health, 2, 1215-1217. doi:10.4236/health.2010.210179

[16] Ezeibe, M.C.O., et al. (2011) Effects of Aluminium-Magnesium Silicate on Newcastle Disease Virus and on recovery of infected chicks. International Journal of Biological Chemistry, 5, 835-839.

[17] Windholz, M.B. (1978) The Merck index. Merck and Co. Inc., New Jersey.

[18] Foster, E. and Smith, K. (2007) Aluminium-Magnesium Silicate used as antacid, antiulcer and to control diarrhea. Journal of Renal Nutrition, 4, 50-53.

[19] Greene, C.E. (1990) Infectious diseases of dogs and cats. W. B. Saunders, Philadephia.

[20] Murray, K.R. (2000) Harpers biochemistry. McGraw Hill, New York. 